\title{
AN ANALYSIS OF LEXICAL COHESION FOUND IN "NEVER SAY NEVER" SONG LYRICS
}

\author{
Vivi Yulia Pratiwi ${ }^{1}$, Yeni Dwi Jayanti ${ }^{2}$, Isry Laila Syathroh ${ }^{3}$ \\ ${ }^{1}$ IKIP Siliwangi \\ ${ }^{2}$ IKIP Siliwangi \\ ${ }^{3}$ IKIP Siliwangi \\ ${ }^{1}$ viviyuliapratiwi@gmail.com, ${ }^{2}$ yeni.dwi.j@gmail.com, ${ }^{3}$ islaisya@yahoo.com
}

\begin{abstract}
The purpose of this study is to describe kinds of lexical cohesion and to know frequent lexical cohesion used to support the cohesiveness of discourse in Justin Bieber and Jaden Smith's song entitled "Never Say Never". The subject of this study is "Never Say Never" song lyrics. This study uses descriptive qualitative that focuses on lexical cohesion in particular synonym, repetition (anaphora and epistrophe repetition) and antonym. The instrument that the researchers used are books, earphone, youtube and other supporting tools. From this study, the result shows that the lyrics of "Never Say Never" song contains eleven forms of lexical cohesion, consisting of two synonyms, seven repetitions, and two antonyms. So the most frequent occurrence in the data is repetition. The function of lexical cohesion is to make the lyrics have harmonization that makes the lyrics more meaningful.
\end{abstract}

Keywords: antonym, lexical cohesion, repetition, synonym

\section{INTRODUCTION}

Language is an important communication tool for human life. It is supported by Parmawati (2018) that language has central role on intellectual development, social, and emotional students to supported success student and learn all of lessons. Certainly, without language human can find the difficulties to communicate each other. Risdianto (n.d.) defines that language is a system of sounds and words used by humans to express their thoughts and fellings. Furthermore, Susanto, Dias., Walik (2017) state that language is an arbitrary system of sounds or sequences of speech sounds which is used or can be used to interpersonal communication.regarding the use of language, the writer can say that language occupy the important role of human interaction in many areas to communication.

Discourse is a language level that has linguistic support units which include phonemes, morphemes, words, phrases, sentences, and paragraphs. Discourse is one of the most complex linguistic elements because discourse is the linguistic level that has the most complete language unit and is the highest and largest grammatical unit (Chaily, 2011). The form can be speech, advertising, ordinary conversation, poetry, novel, and music.

In the use of a discourse in communicate, required the harmony of one element to other in order to create a good understanding, called cohesion. According to Mulatsih (cited in Dewi, Hernawan and Apsari, 2019), a good content consists of cohesive and coherent information that make the reader understand the message easily. Furthermore, Rita (2009) divides cohesion into two, namely grammatical and lexical cohesion. Grammatical cohesion consists of substitution, ellipsis, reference, and conjunction. Meanwhile, lexical cohesion consists of reiteration, which includes; repetition, synonyms, hyponim, metonyms, antonyms, and collocation. 
This study focuses on lexical cohesion in the form of repetitions, and synonym. According to Sakuma (1999:38) in Rita (2009) repetition is called an action that is close to "equating" or "imitating". Repetition can also be said by repeating a word or phrase has been mentioned before, its meaning can be equivalent to "repeat", "Stringing" or "composing" a sentence with the same word. In this study, the researchers focus on anaphora and epistrophe repetion. Tetsuya (1987:173) in Rita (2009) suggests that synonyms are words that have similar meanings, as revealed below. Here shows a "synonym" whose meaning is not absolutely equal and there is nothing wrong if it says "almost the same meaning".

The data were taken from "Never Say Never" song lyrics that popularized by Justin Bieber and Jaden Smith. The lyrics in this song are poems that emphasize expression individual feeling of the singer. This song is the theme song of "The Karate Kid" movie, and the one of most popular songs in 2011. This song contains lyrics about the difficulties of life and never give up on it.

From the explanation above, the purpose of this study is to describe the kinds of lexical cohesion in particular synonyms, repitition (anaphora and epistrophe repetition), and antonyms. In addition, to know the type of frequent occurrence lexical cohesion in "Never Say Never" song lyrics.

\section{METHOD}

This study use decriptive qualitative method. According to Sugiyono (2005) states that descriptive method is a method used to describe or analyze a research result but not used to make broader conclusions. According to Tavakoli (2012, cited in Aryana and Apsari, 2018), data analysis is "The process of reducing accumulated data collected in research to a manageable size, developing summaries, and looking for patterns". Based on qualitative method and the data that used, the researchers use document analysis technique to collect the data. Procedure of this study are : 1) Looking for the data that will be the object of the research. 2) Determine the object of the research. 3) Identify the data which is a marker of repetition and synonym 4) Classify markers of the data 5) Calculating the frequency use of repetition and synonym in the data 6) Analyzing and create the description use of repetition and synonym.

\section{RESULTS AND DISCUSSION}

\section{Results}

The results presented are the analysis of lexical cohesion in particular synonym, repetition and antonym in the one of the most popular song in 2011 and popularized by one of most famous singers in the world Justin Bieber and Jaden Smith. In this study the data were taken from song lyrics entitled "Never Say Never". The object of this study is lexical cohesion aspect particularly synonym, repetition and antonym that appears in the song lyrics.

For more details see the following table on the frequency of occurrences of synonym, repetition and antonym in the song lyrics "Never Say Never".

Table 1. Table appearance of synonym, repetition and antonym.

\begin{tabular}{cc}
\hline $\begin{array}{c}\text { Category of Lexical Cohesion that } \\
\text { appear }\end{array}$ & "Never say never" \\
\hline Synonym & 2 \\
Repetition & 7
\end{tabular}




\begin{tabular}{cc}
\hline Antonym & 2 \\
\hline Total & 11 \\
\hline
\end{tabular}

\section{Discussion}

Table 2. Table of Data Identification

\begin{tabular}{|c|c|}
\hline \multicolumn{2}{|l|}{ Data Identification } \\
\hline Song Lyric & No. Data \\
\hline Never say never & 1 \\
\hline See I never thought that I could walk through fire & 2 \\
\hline I never thought that I could take the burn & 3 \\
\hline I never had the strength to take it higher & 4 \\
\hline Until I reached the point of no return & 5 \\
\hline And there's just no turning back & 6 \\
\hline When your heart's under attack & 7 \\
\hline Gonna give everything I have & 8 \\
\hline It's my destiny & 9 \\
\hline I will never say never! & 10 \\
\hline I will fight till forever! & 11 \\
\hline Whenever you knock me down & 12 \\
\hline I will not stay on the ground & 13 \\
\hline Pick it up $(3 x)$ & 14 \\
\hline And never say never & 15 \\
\hline I never thought that I could feel this power & 16 \\
\hline I never thought that I could feel this free & 17 \\
\hline I'm strong enough to climb the highest tower & 18 \\
\hline And I'm fast enough to run across the sea & 19 \\
\hline And there's just no turning back & 20 \\
\hline When your heart's under attack & 21 \\
\hline Gonna give everything I have & 22 \\
\hline 'Cause this is my destiny & 23 \\
\hline I will never say never! & 24 \\
\hline I will fight till forever! & 25 \\
\hline Whenever you knock me down & 26 \\
\hline I will not stay on the ground & 27 \\
\hline Pick it up $(3 x)$ & 28 \\
\hline And never say never & 29 \\
\hline Here we go! & 30 \\
\hline Guess who? & 31 \\
\hline Jsmith and JB! & 32 \\
\hline I gotcha little bro & 33 \\
\hline I can handle him & 34 \\
\hline Hold up, aight? & 35 \\
\hline
\end{tabular}


I can handle him 36

$\begin{array}{ll}\text { Now he's bigger than me } & 37\end{array}$

Taller than me $\quad 38$

And he's older than me $\quad 39$

And stronger than me $\quad 40$

And his arms a little bit longer than me 41

But he ain't on a JB song with me! $\quad 42$

I'll be trying to chill 43

They be trying to sour the thrill 44

No pun intended, was raised by the power of Will 45

Like Luke with the force, if push comes to shove 46

Like Kobe in the 4th, ice water with blood 47

I gotta be the best, and yes $\quad 48$

We're the flyest 49

Like David and Goliath $\quad 50$

I conquered the giant $\quad 51$

So now I got the world in my hand $\quad 52$

I was born from two stars $\quad 53$

So the moon's where I land $\quad 54$

I will never say never $\quad 55$

I will fight till forever $\quad 56$

Whenever you knock me down $\quad 57$

I will not stay on the ground $\quad 58$

Pick it up (3x) $\quad 59$

Pick it up, up, up $\quad 60$

And never say never $\quad 61$

I will never say never $\quad 62$

I will fight till forever $\quad 63$

Whenever you knock me down $\quad 64$

$\begin{array}{ll}\text { I will not stay on the ground } & 65\end{array}$

Pick it up (3x) 66

Pick it up, up, up $\quad 67$

And never say never $\quad 68$

Never say never (3x) 69

$\begin{array}{ll}\text { And never say never } & 70\end{array}$

Never say never $(3 \mathrm{x}) \quad 71$

And never say never $\quad 72$

\section{Synonym}

Synonym can be interpreted as another name for objects or things that has phrases that the mean more or less the same as other phrases (Chaer, 1994: 85 in Wahyuni 2016). In this study found the existence of a synonym those are as in the following data. 
Until I reached the point of no return (5)

And there's just no turning back (6)

The word return on the data number (5) is the synonymous with the word turning back on data number (6) and is a synonym of word by word.

No pun intended, was raised by the power of Will (45)

Like Luke with the force, if push comes to shove (46)

The word power on the data number (45) is the synonymous with the word force on data number (46) and is a synonym of word by word.

\section{Repetition}

Repetition is the repetition of lingual units (sounds, syllables, words, and parts of sentences) that are considered important to give the stress in an appropriate context. According to Oxford (2019) Anaphora is the repetion of word or phrase at the beginning of successive clauses. Epistrophe is the repetion of word at the end of successive clauses or sentences.

Based on place repeated in rows, clauses or sentences. In this study found the existence of anaphora repetition as showed in the following data.

I never thought that I could take the burn (3)

I never had the strength to take it higher (4)

I never thought that I could feel this power (16)

I never thought that I could feel this free (17)

Inever on the data are referred to as anaphora repetition because I never is the first word which is then repeated on the data in the next row in the first position, as showed in the data numbers $3,4,16,17$ above.

And there's just no turning back (6) (20)

And never say never (15) (29) (61) (68)

And I'm fast enough to run across the sea (19)

And he's older than me (39)

And stronger than me (40)

And his arms a little bit longer than me (41)

And on the data are referred to as anaphora repetition because and is the first word which is then repeated on the data in the next row in the first position, as showed in the data numbers 6 , $15,19,20,29,39,40,41,61$ and 68 above.

I will never say never! (10) (24) (55) (62)

I will fight till forever! (11) (25) (56) (63)

I will not stay on the ground (13) (27) (58) (65)

I will on the data are referred to as anaphora repetition because $I$ will is the first word which is then repeated on the data in the next row in the first position, as showed in the data numbers 10 , $11,13,24,25,27,55,56,58,62,63$, and 65 above.

So now I got the world in my hand (52) 
So the moon's where I land (54)

So on the data are referred to as anaphora repetition because $S o$ is the first word which is then repeated on the data in the next row in the first position, as showed in the data numbers 52 and 54 above.

Like Luke with the force, if push comes to shove (46)

Like Kobe in the 4th, ice water with blood (47)

Like David and Goliath (50)

Like on the data are referred to as anaphora repetition because like is the first word which is then repeated on the data in the next row in the first position, as showed in the data numbers 46, 47 and 50 above. Besides anaphora repetition is also found epistrophe repetition as showed in the following data.

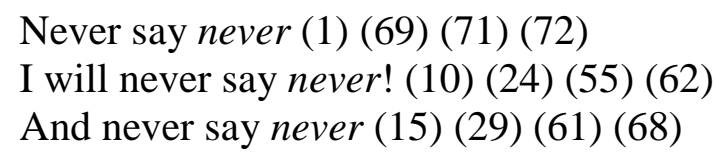

In the data above found epistrophe repetition because the data on the last sentence of number 1 are repeated at number 10, 15, 24, 29, 55, 61, 62, 68, 69, 71, and 72 in the same position at the end of the sentence.

Now he's bigger than me (39)

Taller than me (40)

And he's older than me (41)

And stronger than me (42)

And his arms a little bit longer than me (43)

In the data above found epistrophe repetition because the data on the last sentence of number 39 are repeated at number 40, 41, 42 and 43 in the same position at the end of the sentence.

\section{Antonym}

Antonym can be interpreted as another name for objects or things that has another meaning or has the opposite meaning (Oxford, 2019). In this study found the existence of a antonym those are as in the following data.

Whenever you knock me down (12) (14)

Pick it up (3x) (27) (29)

The phrase knock me down on the data number (12) and (14) are the antonimous with the phrase pick it up (3x) on data number (27) and (29) and is an antonymous of phrase by phrase.

I gotcha little bro (33)

I conquered the giant (51)

The word little on the data number (33) is the antonimous with the word giant on data number (51) and is an antonymous of word by word. 


\section{CONCLUSION}

This study analyzes about lexical cohesion that found in "Never Say Never" song lyrics, the result shows the use of lexical cohesion in particular synonym, repetition (anaphora and epistrophe repetition) and antonym. The lyrics contains eleven forms of lexical cohesion, consisting two synonyms, seven repetitions, and two antonyms. Synonym which are contains in the lyrics are 'return' $><$ 'turning back' and 'power' $><$ 'force'. On the data also found kinds of repetition those are anaphora repetition such as the word 'I never', 'and', 'I will', 'so', 'like' and epistrophe repetition such as in the word 'never' which repeat three times in next row and the word 'than me' which repeat 5 times in the next. To support the unity of the data, in the lyrics also found the antonym such as 'knock me down' $><$ 'pick it up' and 'little' $><$ 'giant'. So the most frequent occurrence of lexical cohesion in the data is repetition. The harmonization of lexical cohesion that appears in the song lyrics make it more meaningful.

\section{ACKNOWLEDGMENTS}

First and foremost, I would like to thank Allah Almighty for giving us the opportunity, stranght and knowledge to undertake this research. Without his blassing, this achievement would not have been possible. We thank to our colleagues from IKIP Siliwangi Bandung who provided insight and expertise that greatly assisted the research. We also like to show our gratitude to our friends for sharing their pearls of wisdom with us during the course of the research, and we thank to reviewers for their insights. We are also grateful for their comments on an earlier version of the manuscript, although any error are our own and should not tarnish the reputation of these esteemed persons.

\section{REFERENCES}

Aryana, S., \& Apsari, Y. (2018). Analysing Teacher's Difficulties In Teaching Listening. Eltin Journal, Journal Of English Language Teaching In Indonesia, 6(2), 100-106.

Chaily, D. (2011). An analysis of Lexical Cohesion in Flannery O'Connors short story, "A good man is hard to find." Medan. University of Sumatera Utara.

Dewi, M. W., Hernawan, K. F., \& Apsari, Y. (2019). Thematic Progression In Students'descriptive Texts. Project (Professional Journal Of English Education), 2(2), 126-132.

Halliday., H. (1997). Cohesion in English. London: Longman Group Limited.

Oxford. (2019). English Oxford Living Dictionaries. Retrieved April 2, 2019, from Oxfod University Press website: https://en.oxforddictionaries.com/definition/anaphora

Parmawati, A. (2018). The Study Correlation Between Reading Habit And Pronunciation Ability At The Second Grade Students Of Ikip Siliwangi. Eltin Journal, Journal Of English Language Teaching In Indonesia, 6(1), 46-52.

Renkema. (1993). Discourse Studies. Amsterdam: Benyamin.

Risdianto, F. (n.d.). Discourse Analysis of song lyric entitled "We Will Not Go Down." IAIN Salatiga.

Rita, S. et al. (2009). Sinonim, Repetisi, Antonim dalam Bahasa Jepang: Telaah majalah

Nihongo Journal dan Hiranaga Times. Jakarta. BINUS Univesity.

Sumarlam, et al. (2003). Teori dan praktik analisi Wacana. Surakarta: Pustaka Cakra.

Susanto, Dias., Walik, S. (2017). The intepersonal meaning in the lyrics of Christina Perri's 
album "Lovestong" and the contribution for teaching a modern English gammar. Deiksis, 09, 283-291.

Wahyuni, S. (2016). Kohesi pada lirik lagu grup Band Gigi dalam album religi "Mohon Ampun" dan implikasinya dalam pembelajaran menulis puisi. Surakarta. Universitas Muhammadiyah Surakarta.

Warnengsih, A. et al. (n.d.). Discourse Analysis of articles of The Japanese magazine from Cohesion aspect. Riau. Universitas Riau. 